Article

\title{
Three New Isoflavonoid Glycosides from the Mangrove-Derived Actinomycete Micromonospora aurantiaca 110B
}

\author{
Rui-Jun Wang ${ }^{1}$, Shao-Yong Zhang ${ }^{3}$, Yang-Hui Ye ${ }^{1}$, Zhen $\mathrm{Yu}^{3}{ }^{3}$, Huan $\mathrm{Qi}^{3}{ }^{3}$, Hui Zhang ${ }^{3}{ }^{\circledR}$, \\ Zheng-Lian Xue ${ }^{2}$, Ji-Dong Wang ${ }^{2,3, *}$ and Min Wu ${ }^{1, *}$ \\ 1 Ocean College, Zhejiang University, Zhoushan 316021, China; 15034663445@163.com (R.-J.W.); \\ yyhleslie@163.com (Y.-H.Y.) \\ 2 College of Biochemical Engineering, Anhui Polytechnic University, Wuhu 241000, China; \\ xuezhen0851@sina.com \\ 3 Zhejiang Key Laboratory of Antifungal Drugs, Zhejiang Hisun Pharmaceutical Co., Ltd., Taizhou 318000, \\ China; 1zhangshaoyong@163.com (S.-Y.Z.); yuzhen@hisunpharm.com (Z.Y.); \\ qihuan@hisunpharm.com (H.Q.); huizhang@hisunpharm.com (H.Z.) \\ * Correspondence: jdwang@hisunpharm.com (J.-D.W.); wumin@zju.edu.cn (M.W.); \\ Tel.: +86-136-3400-5685 (J.-D.W.); +86-136-1651-0066 (M.W.)
}

Received: 4 May 2019; Accepted: 13 May 2019; Published: 17 May 2019

check for updates

\begin{abstract}
The mangrove ecosystem is a rich resource for the discovery of actinomycetes with potential applications in pharmaceutical science. Besides the genus Streptomyces, Micromonospora is also a source of new bioactive agents. We screened Micromonospora from the rhizosphere soil of mangrove plants in Fujian province, China, and 51 strains were obtained. Among them, the extracts of 12 isolates inhibited the growth of human lung carcinoma A549 cells. Strain 110B exhibited better cytotoxic activity, and its bioactive constituents were investigated. Consequently, three new isoflavonoid glycosides, daidzein-4' -(2-deoxy- $\alpha$-L-fucopyranoside) (1), daidzein-7-(2-deoxy- $\alpha$-L-fucopyranoside) (2), and daidzein- $4^{\prime}, 7$-di-(2-deoxy- $\alpha$-L-fucopyranoside) (3) were isolated from the fermentation broth of strain 110B. The structures of the new compounds were determined by spectroscopic methods, including 1D and 2D nuclear magnetic resonance (NMR) and high-resolution electrospray ionization mass spectrometry (HR-ESIMS). The result of medium-changing experiments implicated that these new compounds were microbial biotransformation products of strain M. aurantiaca 110B. The three compounds displayed moderate cytotoxic activity to the human lung carcinoma cell line A549, hepatocellular liver carcinoma cell line HepG2, and the human colon tumor cell line HCT116, whereas none of them showed antifungal or antibacterial activities.
\end{abstract}

Keywords: Micromonospora aurantiaca 110B; isoflavonoid glycosides; structure elucidation; cytotoxic activity

\section{Introduction}

The mangrove ecosystem, distinguished by its land-to-ocean transition, is complex and special. Mangroves thrive in a stressful environment of high salinity, high moisture, strong winds, and high osmotic pressure [1]. This environment breeds a distinctive microbial community that can tolerate numerous stresses and has developed unique metabolic pathways for the purpose of structural ecological adaptability [2,3]. Recent research has focused on the diversity of mangrove microorganisms and their metabolic compounds [4-6]. Among mangrove microorganisms, actinomycetes have gained more attention due to their ability to produce impressive numbers of bioactive metabolites [3]. There is clear evidence that the mangrove ecosystem contains a large diversity of actinomycetes [7]. As one of 
the genera of actinomycetes, the genus Micromonospora is an important prolific producer of secondary metabolites $[8,9]$.

The genus Micromonospora, belonging to the family Micromonosporaceae, was proposed by Ørskov [10]. Currently, this genus consists of more than 80 recognized species, according to the List of Prokaryotic Names with Standing in Nomenclature (LPSN) [11]. About 20 new species of Micromonospora have been isolated in the last five years. Many of them were isolated from mangrove environments, such as Micromonospora sediminis $\mathrm{CH} 3-3^{\mathrm{T}}$ [12], Micromonospora ovatispora 2701 SIM06 ${ }^{\mathrm{T}}$ [13], Micromonospora zhanjiangensis $2902 \mathrm{at} 01^{\mathrm{T}}$ [14], Micromonospora sonneratiae $274745^{\mathrm{T}}$ [15], and Micromonospora maritima D10-9-5 ${ }^{\mathrm{T}}$ [16]. Meanwhile, some new metabolites with biological activities have been isolated from the mangrove-derived Micromonospora strains. Micromonospora rifamycinica AM105 produced rifamycin $S$ and the geometric isomer of rifamycin $S$ with antimicrobial activity against methicillin-resistant Staphylococcus aureus (MRSA) [17]. Butremycin was isolated from Micromonospora sp. K310 and displayed weak antibacterial activity against Gram-positive Staphylococcus aureus ATCC 25923 and Gram-negative Escherichia coli ATCC 25922 [18]. 3-Methyl-carboline from Micromonospora sp. M2DG17 showed weak inhibitory activity on human colon carcinoma HCT 116 cell lines [19].

In our continuing study of mangrove actinomycetes, 51 strains of Micromonospora were isolated from the rhizosphere soil of mangrove plants in Fujian province. The crude extracts obtained from the isolates were evaluated for cytotoxic activity. Based on the cytotoxic activity, further chemical investigations were performed on Micromonospora aurantiaca 110B. As a result, three new isoflavonoid glycosides (1-3) were isolated from its fermentation broth. Herein, we describe the isolation, structure elucidation, and cytotoxic activity of these three new compounds.

\section{Results}

\subsection{Isolation and Screening of Strains for Cytotoxic Activities}

Fifty-one strains belonging to the genus Micromonospora were isolated from mangrove soil samples. The crude extracts of these isolates were examined for their cytotoxic activity. After primary screening, 12 strains showed cytotoxic activity to the human lung tumor cell line A549 (Figure 1). The 16S rRNA genes of the 12 strains were sequenced and the sequences were blasted against GenBank (https://www.ncbi.nlm.nih.gov/genbank/). The results showed that the isolates belonged to seven different species (Figure 2) and that strain 110B was closely related to the type strain Micromonospora aurantiaca ATCC $27029^{\mathrm{T}}$ (CP002162).

Due to the superior cytotoxic activity of strain $110 \mathrm{~B}$, further chemical investigations were performed on this strain.

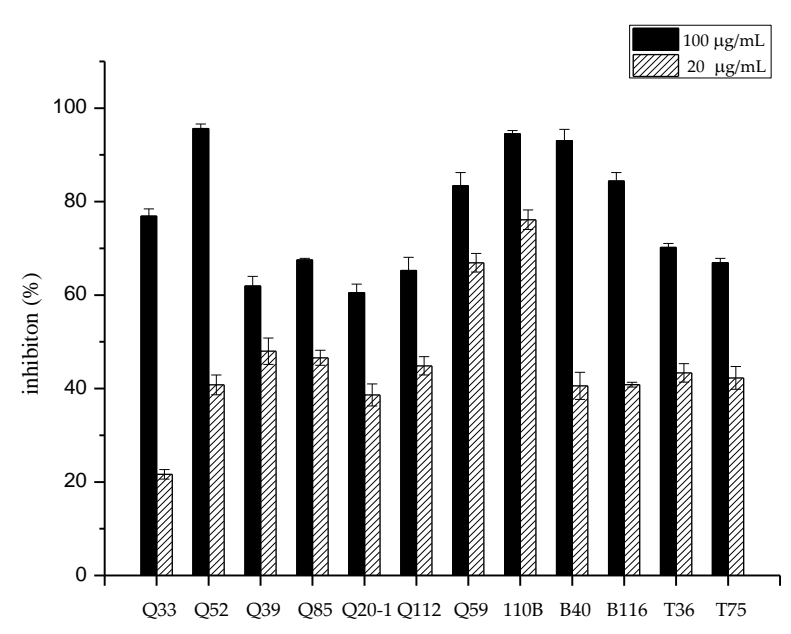

Figure 1. Cytotoxic activity of extracts obtained from 12 isolates against the human lung tumor cell line A549 in vitro. 


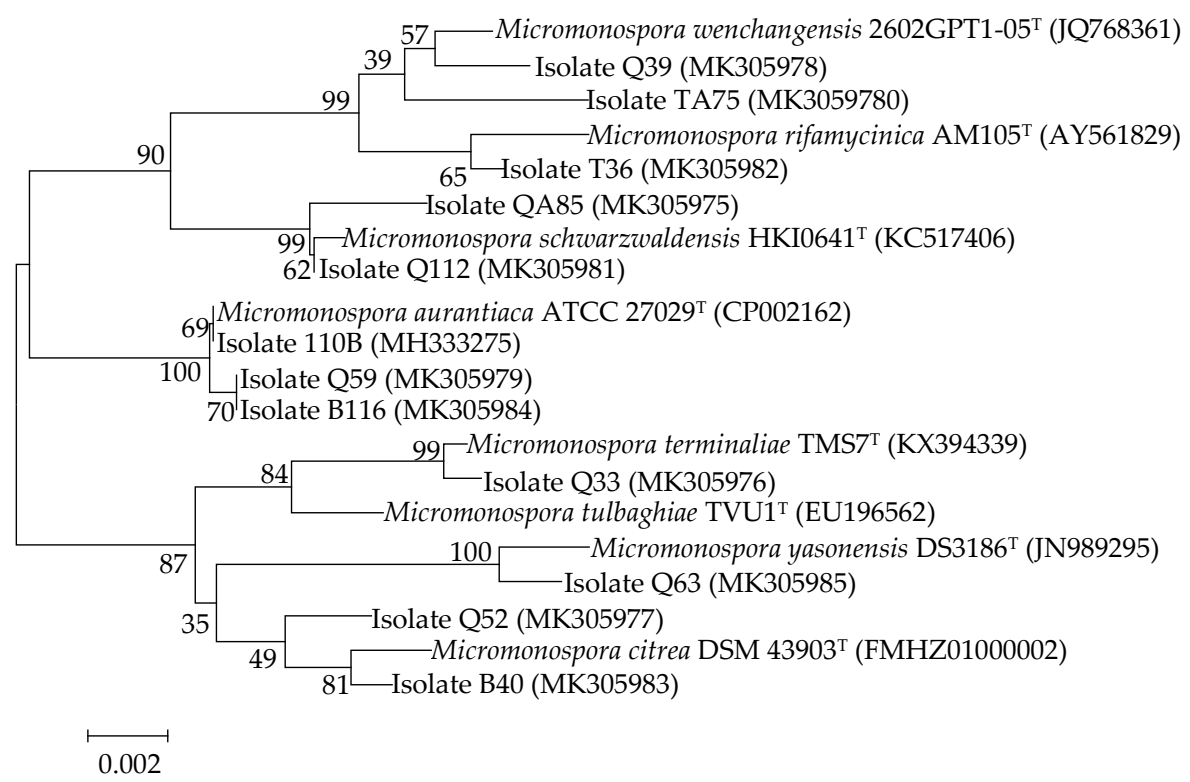

Figure 2. Neighbor-joining phylogenetic tree based on nearly complete $16 \mathrm{~S}$ rRNA gene sequences showing relationships between the 12 active isolates and the type strains of the highest $16 \mathrm{~S}$ rDNA sequence similarity. Bootstrap values were based on 1000 replicates; only values $\geq 50 \%$ are shown. Bar: 0.002 substitutions per nucleotide position.

\subsection{Structural Elucidation}

The strain 110B was grown in a preparative scale in $30 \mathrm{~L}$ of fermentation medium for 7 days. A chemical investigation of its fermentation broth led to the isolation of three new isoflavonoid glycosides (compounds 1-3).

Compound 1 was obtained as a white powder with a negative specific rotation value $\left([\alpha]_{\mathrm{D}}^{25}-107\right.$, $\mathrm{EtOH})$ and $\mathrm{UV}(\mathrm{EtOH}) \lambda_{\max }(\log \varepsilon) 249$ (4.49), $301(4.10) \mathrm{nm}$. The molecular formula of 1 was established to be $\mathrm{C}_{21} \mathrm{H}_{20} \mathrm{O}_{7}$ from positive-ion HR-ESIMS (Figure $\mathrm{S} 1$ ) and ${ }^{13} \mathrm{C}$ NMR spectral (Figure 44 ) data (Table 1). The IR spectrum (Figure S2) of 1 revealed carbonyl group absorption at $1628 \mathrm{~cm}^{-1}$ and hydroxy group absorption at $3353 \mathrm{~cm}^{-1}$. The ${ }^{1} \mathrm{H}$ NMR (Figure S3) data (Table 1) showed the characteristic isoflavone signal for $\mathrm{H}-2$ at $\delta_{\mathrm{H}} 8.08(1 \mathrm{H}, \mathrm{s})$; two sets of aromatic hydrogen peaks at $\delta_{\mathrm{H}} 7.39(2 \mathrm{H}, \mathrm{d}, J=8.7 \mathrm{~Hz})$ and $\delta_{\mathrm{H}} 7.05(2 \mathrm{H}, \mathrm{d}, J=8.7 \mathrm{~Hz})$ corresponding to a 4-hydroxyphenyl moiety (B ring); three aromatic protons corresponding to a 7-substituted A ring at $\delta_{\mathrm{H}} 7.97(1 \mathrm{H}, \mathrm{d}, J=9.0 \mathrm{~Hz}), 6.84(1 \mathrm{H}, \mathrm{dd}, J=9.0,2.4 \mathrm{~Hz})$, and $\delta_{\mathrm{H}} 6.76(1 \mathrm{H}, \mathrm{d}, J=2.4 \mathrm{~Hz})$; and nine proton signals attributable to sugars at $\delta_{\mathrm{H}} 5.62(1 \mathrm{H}, \mathrm{br} \mathrm{d}$, $J=3.5 \mathrm{~Hz}), 4.09(1 \mathrm{H}, \mathrm{ddd}, J=11.9,5.0,3.0 \mathrm{~Hz}), 3.89(1 \mathrm{H}, \mathrm{q}, J=6.6 \mathrm{~Hz}), 3.55(1 \mathrm{H}, \mathrm{br} \mathrm{d}, J=3.0 \mathrm{~Hz}), 2.03$ $(1 \mathrm{H}, \mathrm{ddd}, J=12.8,11.9,3.6 \mathrm{~Hz}), 1.90(1 \mathrm{H}, \mathrm{dd} J=12.8,5.0 \mathrm{~Hz})$, and $\delta_{\mathrm{H}} 1.10(3 \mathrm{H}, \mathrm{d}, J=6.6 \mathrm{~Hz})$. The ${ }^{13} \mathrm{C}$ NMR spectrum (Table 1) displayed 21 carbon resonances, including 15 carbons for the isoflavone skeleton and 6 carbons for the sugar. The NMR spectral (Figure S6) data suggested that compound 1 was an isoflavone glycoside, and the isoflavone skeleton proved to be daidzein based on a comparison of the spectroscopic data with previously reported values $[20,21]$. The 6-carbon resonances of sugar can be categorized as 1 methyl $\left(\delta_{C}\right.$ 18.4), 1 methylene $\left(\delta_{C}\right.$ 32.09), 1 acetal $\left(\delta_{C}\right.$ 97.6), and 3 methines $\left(\delta_{\mathrm{C}} 72.1,68.6,66.7\right)$ by ${ }^{13} \mathrm{C}$ NMR and distortionless enhancement by polarization transfer (DEPT, Figure S5) experiments, indicating the presence of a 2,6-dideoxysugar moiety. The correlations of $\mathrm{H}-1^{\prime \prime} / \mathrm{H}_{2}-2^{\prime \prime} / \mathrm{H}-3^{\prime \prime} / \mathrm{H}-4^{\prime \prime} / \mathrm{H}-5^{\prime \prime} / \mathrm{H}_{3}-6^{\prime \prime}$ in the ${ }^{1} \mathrm{H}-{ }^{1} \mathrm{H}$ correlation spectroscopy (COSY) spectrum (Figure 3 and Figure S7) and the observed heteronuclear multiple bond correlation (HMBC) signals (Figure 3 and Figure S8) from $\mathrm{H}-1$ " to $\mathrm{C}-5$ " and $\mathrm{H}_{3}-6$ " to $\mathrm{C}-4$ " further established the 2,6-dideoxysugar structure. In the HMBC experiment, the correlation between the anomeric proton $\left(\mathrm{H}-1^{\prime \prime}\right)$ and the carbon at $\delta_{\mathrm{C}}$ $158.3\left(\mathrm{C}-4^{\prime}\right)$ confirmed the attachment of the sugar moiety to the phenolic $4^{\prime}-\mathrm{O}$-atom. From the detailed analysis of the ${ }^{1} \mathrm{H}$ NMR spectrum, the small coupling constant of $\mathrm{H}-1$ " $\left(\delta_{\mathrm{H}} 5.62 \mathrm{br} \mathrm{d}, J=3.5 \mathrm{~Hz}\right)$ revealed that the sugar is $\alpha$-glycosidically linked to the phenolic oxygen atom [22]. The signal patterns 
of $\mathrm{H}-3^{\prime \prime}\left(\delta_{\mathrm{H}} 4.09 \mathrm{ddd}, J=11.9,5.0,3.0 \mathrm{~Hz}\right)$ and $\mathrm{H}-4 "{ }^{\prime \prime}\left(\delta_{\mathrm{H}} 3.55 \mathrm{br} \mathrm{d}, J=3.0 \mathrm{~Hz}\right)$ showed equatorial 3"-OH and axial $4^{\prime \prime}-\mathrm{OH}$ groups. Further, signals at $\mathrm{H}-4$ " exhibited 3.0 coupling, which could be assigned to the axial H-5" and axial H-3", respectively. This 2,6-dideoxysugar was assumed to be 2-deoxy-L-fucose on the basis of ${ }^{1} \mathrm{H}$ and ${ }^{13} \mathrm{C}$ NMR data $[23,24]$ and the NOESY experiment (Figure S9). Acid hydrolysis of compound 1 afforded the aglycone daidzein and a 2-deoxy-L-fucose. The aglycone fraction was identified by HPLC analysis. The retention time of the aglycone moiety of $\mathbf{1}$ was in good agreement with that of daidzein (Figure S28). The sugar fraction liberated by acid hydrolysis was treated with L-cysteine methyl ester, followed by reaction with O-tolylisothiocyanate. By reversed-phase HPLC analysis, the identical retention time of the liberated sugar derivative with that of the 2-deoxy-L-fucose derivative indicated that the sugar moiety of $\mathbf{1}$ was 2-deoxy-fucose (Figure S29). Consequently, the structure of 1 was elucidated to be daidzein- $4^{\prime}$-(2-deoxy- $\alpha$-L-fucopyranoside) (Figures 3 and 4 ).

Compound 2 was obtained as a white powder with a negative specific rotation value $\left([\alpha]_{D}^{25}-112\right.$, EtOH). The molecular formula of 2 was established as $\mathrm{C}_{21} \mathrm{H}_{20} \mathrm{O}_{7}$ from positive-ion HR-ESIMS (Figure S10) and ${ }^{13} \mathrm{C}$ NMR spectral data (Table 1). Bands for hydroxy group at $3357 \mathrm{~cm}^{-1}$ and the carbonyl group at $1634 \mathrm{~cm}^{-1}$ were evident in the IR spectrum (Figure S11). In the ${ }^{1} \mathrm{H}$ NMR spectrum (Table 1) of 2 , the characteristic $\mathrm{H}-2$ signal of an isoflavone was exhibited at $\delta_{\mathrm{H}} 8.12(1 \mathrm{H}, \mathrm{s})$, and the 4-hydroxyphenyl nature of the $B$ ring was deduced from the signals at $\delta_{\mathrm{H}} 7.31(2 \mathrm{H}, \mathrm{d}, J=9.0 \mathrm{~Hz})$ and $\delta_{\mathrm{H}} 6.78(2 \mathrm{H}, \mathrm{d}, J=9.0 \mathrm{~Hz})$. Three aromatic proton signals were observed at $\delta_{\mathrm{H}} 8.06(1 \mathrm{H}, \mathrm{d}, J=9.0 \mathrm{~Hz})$, $7.18 \mathrm{~d}(1 \mathrm{H}, \mathrm{d}, J=2.3 \mathrm{~Hz})$, and $\delta_{\mathrm{H}} 7.09(1 \mathrm{H}, \mathrm{dd}, J=9.0,2.3 \mathrm{~Hz})$, indicating that the A ring was substituted at C-7. An anomeric proton signal at $\delta_{\mathrm{H}} 5.78 \mathrm{~d}(1 \mathrm{H}, \mathrm{br} \mathrm{d}, J=3.6 \mathrm{~Hz})$ also appeared in the ${ }^{1} \mathrm{H} \mathrm{NMR}$ spectrum of $\mathbf{2}$. Comparison of the NMR data (Figures S12-S18) of $\mathbf{2}$ with those of $\mathbf{1}$ revealed close similarities, except for the substituted pattern of the 2,6-dideoxysugar moiety. The observed HMBC correlation (Figure 3) from the anomeric proton H-1" to C-7 $\left(\delta_{C} 163.1\right)$ confirmed the position of the 2,6-dideoxysugar. The 2,6-dideoxysugar was deduced to be 2-deoxy-1-fucose according to HPLC analysis of the corresponding $O$-tolylthiocarbamate derivative of the liberated sugar, as described above. Thus, the structure of $\mathbf{2}$ was identified as daidzein-7-(2-deoxy- $\alpha$-L-fucopyranoside) (Figure 3).

Table 1. ${ }^{1} \mathrm{H}$ and ${ }^{13} \mathrm{C}$ NMR (100 MHz) data of compounds $1-3$ in $\mathrm{CD}_{3} \mathrm{OD}$.

\begin{tabular}{|c|c|c|c|c|c|c|}
\hline \multirow{2}{*}{ Position } & \multicolumn{2}{|r|}{$1^{a}$} & \multicolumn{2}{|r|}{$2^{b}$} & \multicolumn{2}{|r|}{$3^{b}$} \\
\hline & $\delta \mathrm{c}$ & $\delta_{\mathrm{H}}(J$ in $\mathrm{Hz})$ & $\delta \mathrm{c}$ & $\delta_{\mathrm{H}}(J$ in $\mathrm{Hz})$ & $\delta \mathrm{c}$ & $\delta_{\mathrm{H}}(J$ in $\mathrm{Hz})$ \\
\hline 2 & 154.9 & $8.08 \mathrm{~s}$ & 154.9 & $8.12 \mathrm{~s}$ & 155.2 & $8.21 \mathrm{~s}$ \\
\hline 3 & 125.6 & & 126.2 & & 125.9 & \\
\hline 4 & 178 & & 178.1 & & 177.9 & \\
\hline 5 & 128.5 & $7.97 \mathrm{~d}(9.0)$ & 128.2 & $8.06 \mathrm{~d}(9.0)$ & 128.2 & $8.12 \mathrm{~d}(8.9)$ \\
\hline 6 & 116.5 & $6.84 \mathrm{dd}(9.0,2.4)$ & 117.2 & 7.09 dd $(9.0,2.3)$ & 117.2 & 7.15 dd $(8.9,2.2)$ \\
\hline 7 & 164.7 & & 163.1 & & 163.1 & \\
\hline 8 & 103.3 & $6.76 \mathrm{~d}(2.4)$ & 104.4 & $7.18 \mathrm{~d}(2.3)$ & 104.4 & $7.25 \mathrm{~d}(2.2)$ \\
\hline 9 & 159.8 & & 159.4 & & 159.3 & \\
\hline 10 & 118.2 & & 119.8 & & 119.7 & \\
\hline $1^{\prime}$ & 126.7 & & 124.1 & & 125.9 & \\
\hline $2^{\prime}, 6^{\prime}$ & 131.3 & $7.39 \mathrm{~d}(8.7)$ & 131.4 & $7.31 \mathrm{~d}(9.0)$ & 131.3 & $7.47 \mathrm{~d}(8.7)$ \\
\hline $3^{\prime}, 5^{\prime}$ & 117.5 & $7.05 \mathrm{~d}(8.7)$ & 116.3 & $6.78 \mathrm{~d}(9.0)$ & 117.4 & $7.13 \mathrm{~d}(8.7)$ \\
\hline $4^{\prime}$ & 158.3 & & 158.8 & & 158.3 & \\
\hline $1^{\prime \prime}$ & 97.6 & 5.62 br d (3.5) & 98.2 & 5.78 br d (3.6) & 97.6 & 5.69 br d (3.5) \\
\hline $2^{\prime \prime}$ & 32.1 & $\begin{array}{c}2.03 \text { ddd }(12.8,11.9,3.6) \\
1.90 \mathrm{dd}(12.8,5.0)\end{array}$ & 32.9 & $\begin{array}{c}2.07 \text { ddd }(13.2,12.0,3.6) \\
1.96 \mathrm{dd}(13.2,5.0)\end{array}$ & 33.2 & $\begin{array}{c}2.08 \text { ddd }(12.8,12.0,3.5) \\
1.91 \mathrm{dd}(12.8,5.1)\end{array}$ \\
\hline $3^{\prime \prime}$ & 66.7 & 4.09 ddd $(11.9,5.0,3.0)$ & 66.6 & 4.09 ddd $(12.0,5.0,3.0)$ & 66.7 & 4.16 ddd $(12.0,5.1,3.1)$ \\
\hline $4^{\prime \prime}$ & 72.1 & $3.55 \mathrm{br} \mathrm{d}(3.0)$ & 71.9 & 3.57 br d $(3.0)$ & 71.9 & $3.62 \mathrm{~m}$ \\
\hline $5^{\prime \prime}$ & 68.6 & $3.89 \mathrm{q}(6.6)$ & 69.3 & $3.86 \mathrm{q}(6.6)$ & 69.3 & $3.91 \mathrm{~m}$ \\
\hline $6^{\prime \prime}$ & 18.4 & $1.10 \mathrm{~d}(6.6)$ & 17.2 & $1.12 \mathrm{~d}(6.6)$ & 17.2 & $1.18 \mathrm{~d}(6.2)$ \\
\hline $1^{\prime \prime \prime}$ & & & & & 98.2 & 5.84 br d (3.5) \\
\hline $2^{\prime \prime \prime}$ & & & & & 32.9 & $\begin{array}{c}2.12 \text { ddd }(13.1,12.0,3.5) \\
1.98 \text { dd }(13.1,5.1)\end{array}$ \\
\hline $3^{\prime \prime \prime}$ & & & & & 66.5 & 4.13 ddd $(12.0,5.1,3.1)$ \\
\hline $4^{\prime \prime \prime}$ & & & & & 72.1 & $3.62 \mathrm{~m}$ \\
\hline $5^{\prime \prime \prime}$ & & & & & 68.6 & $3.95 \mathrm{~m}$ \\
\hline $6^{\prime \prime \prime}$ & & & & & 17.2 & $1.16 \mathrm{~d}(6.2)$ \\
\hline
\end{tabular}

${ }^{\mathrm{a} 1 \mathrm{H}}(600 \mathrm{MHz}) ;{ }^{\text {b } 1 \mathrm{H}}(400 \mathrm{MHz})$. 


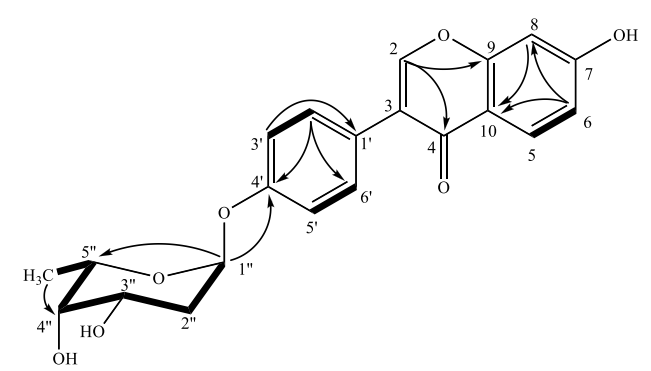

1

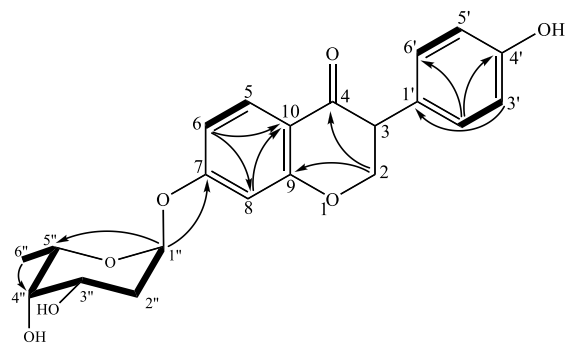

2

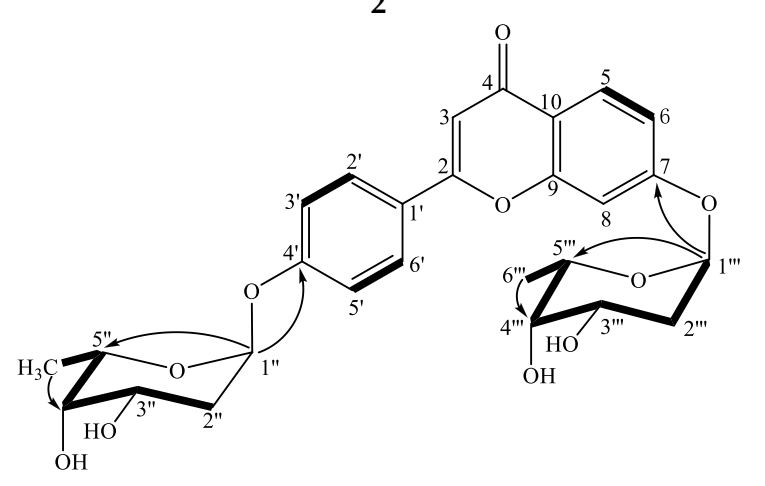

3

${ }^{1} \mathrm{H}^{1}{ }^{1} \mathrm{HCOSY} \longrightarrow \mathrm{HMBC}$

Figure 3. The structures and key ${ }^{1} \mathrm{H}-{ }^{1} \mathrm{H}$ COSY and HMBC correlations for compounds 1-3.

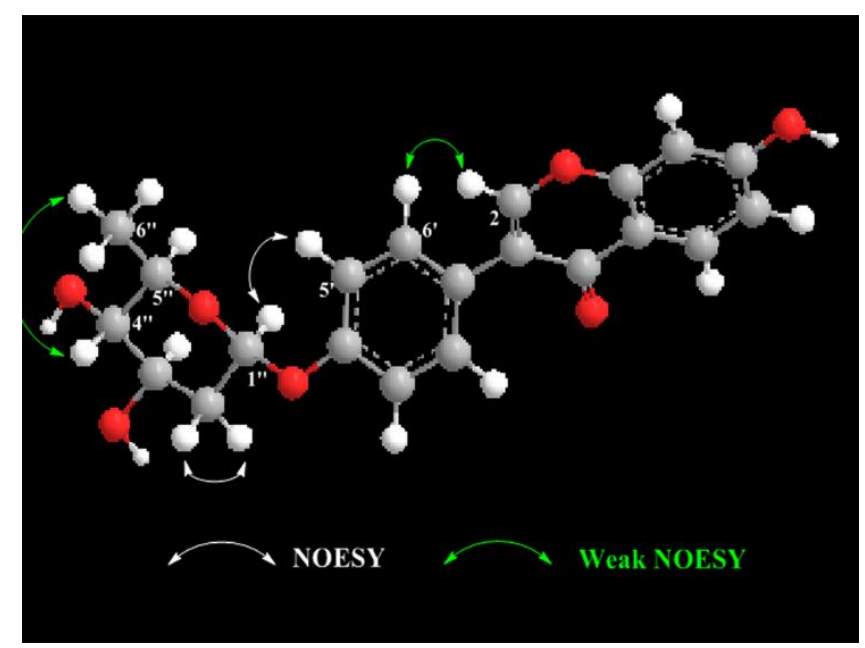

Figure 4. The key NOESY correlations for compound 1.

Compound 3 was obtained as a white powder with a negative specific rotation value $\left([\alpha]_{\mathrm{D}}^{25}-27.0\right.$, EtOH). The molecular formula of 3 was deduced to be $\mathrm{C}_{27} \mathrm{H}_{30} \mathrm{O}_{10}$ from positive-ion HR-ESIMS (Figure S19) and ${ }^{13} \mathrm{C}$ NMR spectral data (Table 1). The IR spectrum (Figure S20) revealed carbonyl absorption at $1650 \mathrm{~cm}^{-1}$ and hydroxy absorption at $3381 \mathrm{~cm}^{-1}$. The ${ }^{1} \mathrm{H}$ NMR spectrum of 3 (Table 1 ) 
showed eight aromatic proton signals at $\delta_{\mathrm{H}} 8.21(1 \mathrm{H}, \mathrm{s}), 8.12(1 \mathrm{H}, \mathrm{d}, J=8.9 \mathrm{~Hz}), 7.47(2 \mathrm{H}, \mathrm{d}, J=8.7 \mathrm{~Hz})$, $7.25(2 \mathrm{H}, \mathrm{d}, J=2.2 \mathrm{~Hz}), 7.15(1 \mathrm{H}, \mathrm{dd}, J=8.9,2.2 \mathrm{~Hz})$, and $\delta_{\mathrm{H}} 7.13(1 \mathrm{H}, \mathrm{d}, J=8.7 \mathrm{~Hz})$, indicating that the isoflavone aglycone of $\mathbf{3}$ was identical to $\mathbf{1}$ and $\mathbf{2}$. Two sugar moieties were evident from the anomeric proton signals at $\delta_{\mathrm{H}} 5.84(1 \mathrm{H}, \mathrm{br} \mathrm{d}, J=3.5 \mathrm{~Hz})$ and $\delta_{\mathrm{H}} 5.69(1 \mathrm{H}, \mathrm{br} \mathrm{d}, J=3.5 \mathrm{~Hz})$ in the ${ }^{1} \mathrm{H} \mathrm{NMR}$ spectrum. The ${ }^{1} \mathrm{H}$ and ${ }^{13} \mathrm{C}$ NMR spectral (Figures S21-S23) data of $\mathbf{3}$ were similar to those of $\mathbf{1}$ and 2, except for an extra 2,6-dideoxysugar moiety. The HMBC (Figure S26) correlations from H-1" to $\mathrm{C}-4^{\prime}$ and $\mathrm{H}-1^{\prime \prime \prime}$ to $\mathrm{C}-7$ revealed that the two 2,6-dideoxysugar moieties were located at C- $4^{\prime}$ and $\mathrm{C}-7$, respectively. The sugar moieties of 3 were determined by HPLC analysis of the $O$-tolylthiocarbamate derivative of the liberated sugar from acid hydrolysis and a standard 2-deoxy-L-fucose derivative. So, the structure of 3 was determined to be daidzein- $4^{\prime}, 7$-di-(2-deoxy- $\alpha$-L-fucopyranoside), as shown in Figure 3.

Isoflavonoids have been frequently isolated from bacterial and fungal cultures, but their biosynthetic origin has not been unveiled in all cases. Not all of the isoflavonoids were synthesized 'de novo'. Ndejouong and Hertweck found that Streptomyces mirabilis could transform isoflavones into hydroxylated and reduced derivatives [25]. In order to clarify whether compounds 1-3 were synthesized 'de novo', we carried out a series of experiments. We prepared different media (media 1-4) to explore whether the ingredients in the fermentation medium will affect the production of compounds $1-3$, and we mainly focused on the medium that lacked soybean cake or peptone. We found that the three new compounds were only detected in medium containing soybean cake. Then, when daidzein was added to the medium lacking soybean cake (giving medium 5), we could observe formation of these new compounds (Figure 5). These results indicated that $M$. aurantiaca 110B could transform plant daidzein into fucosylated derivatives.

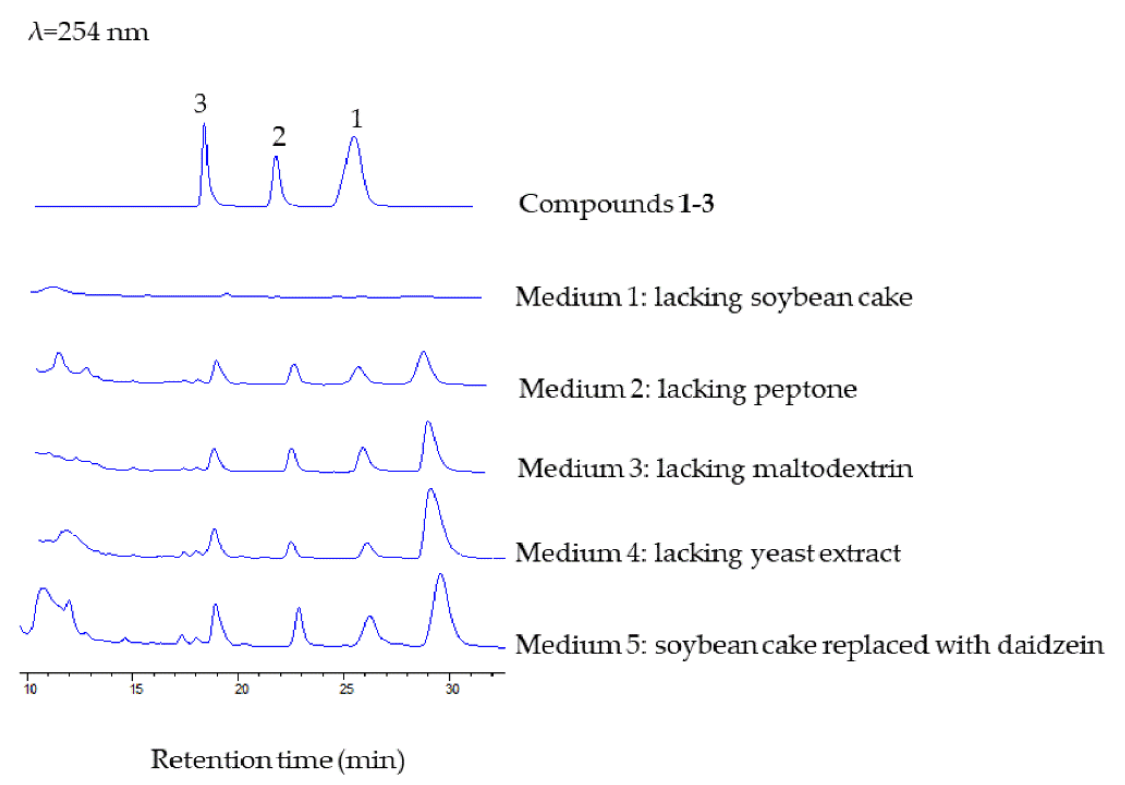

Figure 5. HPLC analysis of the formation of compounds 1-3 in different media, with a mobile phase of $\mathrm{CH}_{3} \mathrm{CN} / \mathrm{H}_{2} \mathrm{O}(25: 75, \mathrm{v} / \mathrm{v})$, flow rate of $1.5 \mathrm{~mL} / \mathrm{min}^{-1}$, and detection wavelength at $254 \mathrm{~nm}$.

\subsection{Analysis of Deoxy-Sugar Glycosyltransferases}

The genome of the strain 110B was sequenced and analyzed. We focused on whether there were any deoxy-sugar-related enzymes in strain $M$. aurantiaca $110 \mathrm{~B}$ because the sugar moieties of the three new isoflavonoid glycosides were 2,6-dideoxysugars. Deoxy-sugar glycosyltransferases are interesting enzymes because of their important role in many natural product drugs. Glycosyltransferase-related protein sequences of the M. aurantiaca 110B were aligned with protein sequences of the UniProt database [26,27], and one protein (AXH94677.1) similar to AknK was found (Figure 6). AknK is an L-2-deoxy-L-fucose transferase found in Streptomyces galilaeus, which catalyzes the addition of the 
second sugar to aclacinomycin A [28]. The genome information of strain 110B also showed that the sugar moieties of the three new isoflavonoid glycosides might be 2-deoxy-fucose. This conclusion was consistent with the results of the structural analysis.

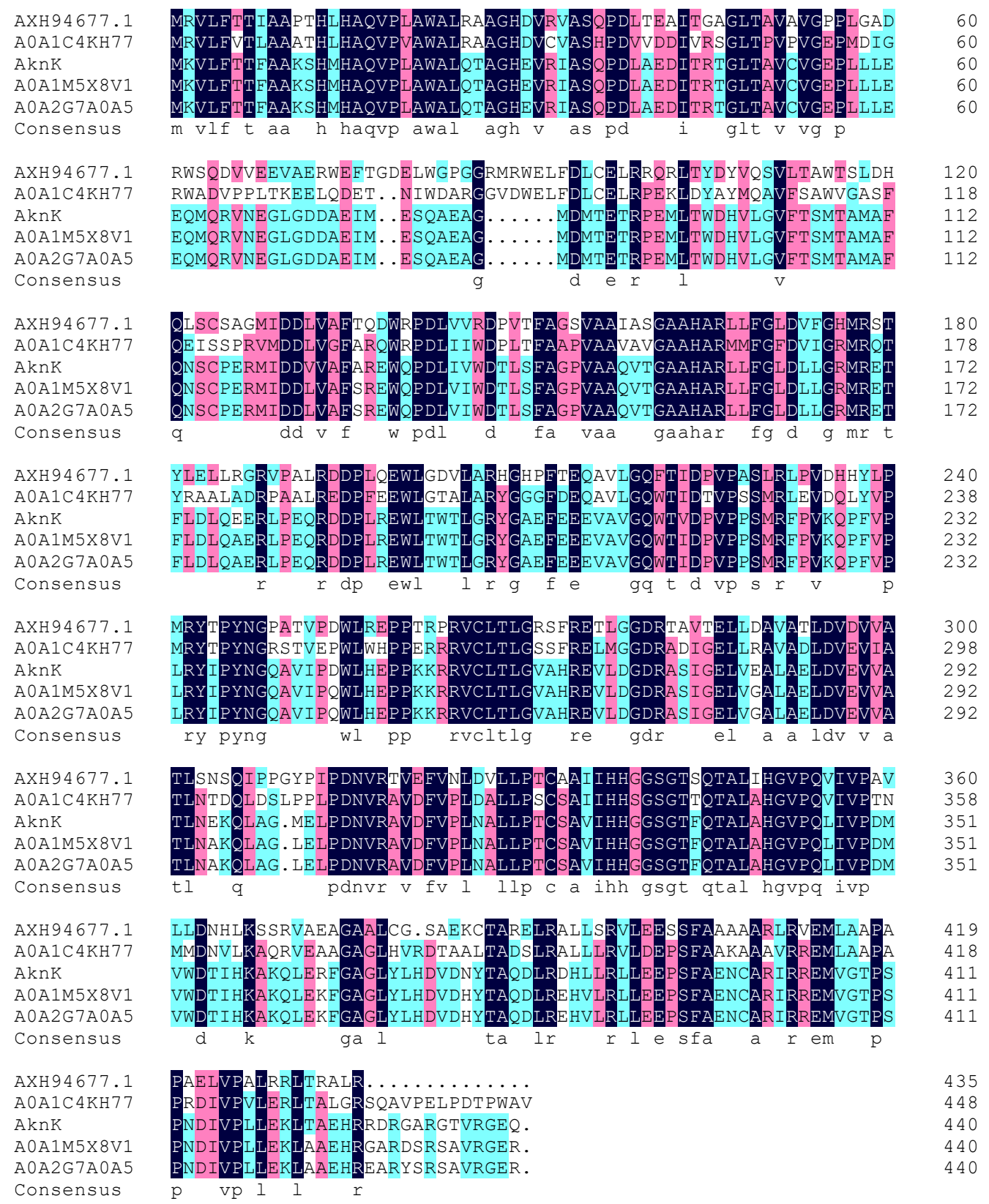

Figure 6. Alignment of the deduced amino acid sequence of AXH94677.1 in strain 110B with different 2-deoxyfucosyltransferases: A0A1C4KH77 (SCD60843.1) from Streptomyces sp. DvalAA-19, AknK (AAF70102.1) from Streptomyces galilaeus, A0A1M5X8V1 (SHH96196.1) from Streptomyces sp. 3214.6, and A0A2G7A0A5 (PIG12760.1) from Streptomyces sp. 1121.2.

\subsection{Biological Activity}

Compounds 1-3 were tested for their activity against the proliferation of the human hepatocellular liver carcinoma cell line HepG2, human lung tumor cell line A549, and human colon tumor cell line HCT116. The results (Table 2) showed that the three compounds exhibited moderate cytotoxic activity against the three cell lines. 
Table 2. Cytotoxic activity of compounds 1-3 against selected human tumor cell lines.

\begin{tabular}{cccc}
\hline \multirow{2}{*}{ Compounds } & \multicolumn{3}{c}{ IC $_{\mathbf{5 0}}(\mu \mathrm{g} / \mathrm{mL})$} \\
\cline { 2 - 4 } & A549 & HepG2 & HCT116 \\
\hline $\mathbf{1}$ & 17.55 & 52.71 & 16.00 \\
$\mathbf{2}$ & 16.95 & 50.90 & 15.40 \\
$\mathbf{3}$ & 14.79 & 44.42 & 13.48 \\
Doxorubicin & 1.02 & 0.86 & 0.91 \\
\hline
\end{tabular}

The antifungal and antibacterial properties of the three compounds were tested against three human pathogens: the fungus Candida albicans, the Gram-positive bacterium methicillin-resistant S. aureus, and the Gram-negative bacterium E. coli. The minimum inhibitory concentrations (MICs) of compounds 1-3 were determined to be $>10 \mathrm{mg} / \mathrm{mL}$, so the new compounds had no activity against these tested pathogens.

\section{Materials and Methods}

\subsection{General Experimental Procedures}

Optical rotation was measured on a Perkin-Elmer 341 polarimeter (Perkin-Elmer, Suzhou, China). IR spectra were recorded on a Nicolet Magna FT-IR 750 spectrometer (Nicolet, Tokyo, Japan). UV spectra were recorded on a Varian CARY 300 BIO spectrophotometer (Varian, Cary, NC, USA). The HR-ESIMS spectra were taken on a Q-TOF Micro LC-MS-MS mass spectrometer (Waters Co, Milford, MA, USA). NMR spectra were measured with a Bruker DRX-400 (400 MHz for ${ }^{1} \mathrm{H}$ and $100 \mathrm{MHz}$ for ${ }^{13} \mathrm{C}$ ) spectrometer (Bruker, Rheinstetten, Germany). HPLC separation was performed on semipreparative HPLC (Agilent 1100, Zorbax SB-C18, $5 \mu \mathrm{m}, 250 \times 9.4 \mathrm{~mm}$ inner diameter; $1.5 \mathrm{~mL} / \mathrm{min} ; 220 \mathrm{~nm}$; Agilent, Palo Alto, CA, USA). Column chromatography was performed with commercial silica gel (Qing Dao Hai Yang Chemical Group Co., 100-200 and 200-300 mesh). Silica gel plates HSGF254 (Yantai Chemical Industry Research Institute, Yantai, China) were used for thin-layer chromatography (TLC).

\subsection{Isolation and Identification of Strain}

Mangrove soils were collected from Zhangzhou $\left(24^{\circ} 20^{\prime}, 117^{\circ} 45^{\prime}\right)$, Fujian province, China. The samples were placed into clean plastic bags and stored at $4{ }^{\circ} \mathrm{C}$ prior to isolation. Samples were dried and mixed with sterile deionized water, and actinobacteria were isolated by plating the resulting suspensions on four different selective isolation media: M6 (raffinose-histidine medium), M8 (glycerol asparagine agar medium), HV (humic acid-vitamin agar), and GP (glucose-tryptone agar medium). All of the media were supplemented with $25 \mathrm{mg} / \mathrm{L}$ of nalidixic acid and $50 \mathrm{mg} / \mathrm{L}$ of nystatin. Also, 10\% supernatant of the strain Micrococcus luteus JCM $21373^{\mathrm{T}}$, which contained resuscitation-promoting factor (rpf), was added to each medium. The strain M. luteus JCM $21373^{\mathrm{T}}$ was inoculated in LMM (lactate minimal medium) at a rate of $5 \%(v / v)$ and incubated at $30^{\circ} \mathrm{C}$ for $48 \mathrm{~h}$ until the end of the logarithmic growth phase [29]. Then, the culture supernatant was collected following centrifugation at $10,000 \mathrm{rpm}$ and sterilized by filtration through a $0.22-\mu \mathrm{m}$ filter. After incubation, isolates with Micromonospora-like morphology were transferred to ISP medium 2 (yeast extract-malt extract agar) and incubated for $7-10$ days at $28^{\circ} \mathrm{C}$.

All isolates were grown in marine broth 2216 (MB, difco) medium for 5 days at $30^{\circ} \mathrm{C}$. Genomic DNA was extracted using the Bacteria Genomic DNA Extraction Kit (DongSheng Biotech) according to the manufacturer's instructions. For phylogenetic studies, the 16S rRNA gene was amplified using two universal primers: 27F (5'-GAGTTTGATCCTGGCTCAG-3') and 1492R (5'-AGAAAGG AGGTGATCCAGCC-3') [30]. Amplification reactions were prepared in a $25-\mu \mathrm{L}$ final reaction volume containing $11 \mu \mathrm{L}$ of distilled water, $12.5 \mu \mathrm{L}$ of PCR SuperMix, $1 \mu \mathrm{L}$ of each primer $(2.5 \mu \mathrm{M})$, and $0.5 \mu \mathrm{L}$ of extracted DNA (template). PCR was performed under the following conditions: 30 cycles of $94{ }^{\circ} \mathrm{C} / 5 \mathrm{~min}, 4^{\circ} \mathrm{C} / 30 \mathrm{~s}, 55^{\circ} \mathrm{C} / 30 \mathrm{~s}, 72{ }^{\circ} \mathrm{C} / 75 \mathrm{~s}$, and a final extension of $72{ }^{\circ} \mathrm{C} / 10 \mathrm{~min}$. PCR products 
were detected by agarose gel electrophoresis. The obtained sequence of each strain was assembled with DNASTAR SeqMan (LaserGene, Madison, WI). The 16S rRNA gene sequence was analyzed using the ExTaxon-e service [31] and the BLASTN program (https://blast.ncbi.nlm.nih.gov/Blast.cgi). For phylogenetic analysis, multiple sequence alignment was accomplished via the CLUSTAL W program of the MEGA 5 package [32]. The strain 110B was identified as M. aurantiaca because its $16 \mathrm{~S}$ rRNA sequence (accession no: MH333275 in the GenBank) exhibited a high sequence similarity of $100 \%$ with that of M. aurantiaca ATCC $27029^{\mathrm{T}}$ (accession no: CP002162).

\subsection{Preparation of Crude Extracts}

All strains were inoculated into 250-mL Erlenmeyer flasks containing $30 \mathrm{~mL}$ of MB medium and incubated at $28^{\circ} \mathrm{C}$ for 7 days while shaking at $200 \mathrm{rpm}$. After cultivation, $60 \mathrm{~mL}$ of methanol was added to each of the cultures. After $24 \mathrm{~h}$, the mixture was filtered and concentrated under vacuum. The extracts were dissolved in dimethyl sulfoxide for cytotoxic evaluation.

\subsection{Fermentation and Extraction of Strain $110 B$}

Strain 110B was inoculated into a 1000-mL flask containing $250 \mathrm{~mL}$ of seed culture medium consisting of (in \%) malt extract (1.0), glucose (0.4), yeast extract (0.4), and $\mathrm{CaCO}_{3}(0.2)$, with a pH of 7.2-7.4. Incubation was carried out at $28^{\circ} \mathrm{C}$ for 3 days on a rotary shaker operating at $250 \mathrm{rpm}$. Then, a $5.0 \%$ seed culture broth was cultured in a 50-L fermenter (containing $30 \mathrm{~L}$ of fermentation medium) at $28^{\circ} \mathrm{C}$ for 7 days. The fermentation medium was a modified 2216 medium which contained (per liter distilled water): soybean cake $(20 \mathrm{~g})$, maltodextrin $(10 \mathrm{~g})$, peptone $(5.0 \mathrm{~g})$, yeast extract $(10 \mathrm{~g})$, glucose $(10 \mathrm{~g}), \mathrm{NaCl}(19.45 \mathrm{~g}), \mathrm{MgCl}_{2} \cdot 6 \mathrm{H}_{2} \mathrm{O}(12.6 \mathrm{~g}), \mathrm{MgSO}_{4} \cdot 7 \mathrm{H}_{2} \mathrm{O}$ (6.64 g), $\mathrm{CaCl}_{2}(1.8 \mathrm{~g}), \mathrm{KCl}(0.55 \mathrm{~g}), \mathrm{NaHCO}_{3}$ (0.16 g), $\mathrm{H}_{3} \mathrm{BO}_{3}(22.0 \mathrm{mg}), \mathrm{KBr}(0.08 \mathrm{~g}), \mathrm{Na}_{2} \mathrm{SiO}_{3}(4.0 \mathrm{mg}), \mathrm{NaF}(2.4 \mathrm{mg}), \mathrm{NH}_{4} \mathrm{NO}_{3}(1.6 \mathrm{mg}), \mathrm{Na}_{2} \mathrm{PO}_{4}$ $(8.0 \mathrm{mg}), \mathrm{SrCl}_{2} \cdot 6 \mathrm{H}_{2} \mathrm{O}(57 \mathrm{mg})$, and ferric citrate $(0.1 \mathrm{~g})$.

The final $30 \mathrm{~L}$ of fermentation broth was centrifuged to separate the mycelial cake and supernatant. The mycelial cake was washed with water $(3 \mathrm{~L})$ and subsequently extracted with $\mathrm{MeOH}(3 \mathrm{~L})$. The supernatant and the wash water were passed through a Diaion HP-20 resin column (Mitsubushi Chemical Co, Ltd., Tokyo, Japan) and eluted with 95\% EtOH. The $\mathrm{MeOH}$ extract and the EtOH eluents were evaporated under reduced pressure to yield a mixture $(25 \mathrm{~g})$ at $50{ }^{\circ} \mathrm{C}$. The mixture was chromatographed on a silica gel column (Qingdao Haiyang Chemical Group, Qingdao, China; 100-200 mesh) and successively eluted with $\mathrm{CHCl}_{3} / \mathrm{MeOH}(100: 0,98: 2,95: 5,90: 10,85: 15,80: 20,70: 30$, 60:40, and 50:50 v/v) to give six fractions (Fr.1-6) based on the TLC profiles. After the Fr.3 was concentrated in vacuo, the material was subjected to a Sephadex LH-20 gel column (GE Healthcare, Glies, UK), eluted with $\mathrm{CHCl}_{3} / \mathrm{MeOH}(1: 1, v / v)$, and detected using TLC to give three fractions (Fr.3-1-3-3). Fr.3-2 was further analyzed and purified by semipreparative reversed-phase HPLC eluting with $\mathrm{CH}_{3} \mathrm{CN} / \mathrm{H}_{2} \mathrm{O}(30: 70, v / v)$ to give compounds $1\left(t_{\mathrm{R}} 15.5 \mathrm{~min}, 12.2 \mathrm{mg}\right)$ and $2\left(t_{\mathrm{R}} 13.5 \mathrm{~min}\right.$, $10.1 \mathrm{mg})$. Fr.4 was subjected to a Sephadex $\mathrm{LH}-20$ column eluted with $\mathrm{CHCl}_{3} / \mathrm{MeOH}(1: 1, v / v)$ and detected by TLC to give three subfractions (Fr.4-1-4-3). Fr.4-2 was further separated by semipreparative reversed-phase HPLC eluting with $\mathrm{CH}_{3} \mathrm{CN} / \mathrm{H}_{2} \mathrm{O}(30: 70, v / v)$ to give compound $3\left(t_{\mathrm{R}} 10.6 \mathrm{~min}, 8.9 \mathrm{mg}\right)$.

Compound 1: white powder; $[\alpha]_{\mathrm{D}}^{25}-107$ (c 0.04, EtOH); IR (KBr) $v_{\max } 3663,3553,2984,2905,1628,1407$, $1049 \mathrm{~cm}^{-1}$; UV (EtOH) $\lambda_{\max }(\log \varepsilon) 249(4.49), 301(4.10) \mathrm{nm} ;{ }^{1} \mathrm{H}(400 \mathrm{MHz})$ and ${ }^{13} \mathrm{C}$ NMR $(100 \mathrm{MHz})$ data, see Table 2; positive HR-ESIMS $m / z 385.1286[\mathrm{M}+\mathrm{H}]^{+}$(calcd. for $\mathrm{C}_{21} \mathrm{H}_{21} \mathrm{O}_{7}, 385.1282$ ).

Compound 2: white powder; $[\alpha]_{\mathrm{D}}^{25}-112$ (c 0.04, EtOH); IR (KBr) $v_{\max } 3357,2984,2838,1634,1408$, $1023 \mathrm{~cm}^{-1}$; UV (MeOH) $\lambda_{\max }(\log \varepsilon) 249$ (4.18), 262 (4.23), 305 (3.76) nm; ${ }^{1} \mathrm{H}(400 \mathrm{MHz})$ and ${ }^{13} \mathrm{C} \mathrm{NMR}$ $(100 \mathrm{MHz} \text { ) data, see Table 2; positive HR-ESIMS } m / z \text { 385.1287 [M + H] }]^{+}$(calcd. for $\mathrm{C}_{21} \mathrm{H}_{21} \mathrm{O}_{7}, 385.1282$ ).

Compound 3: white powder; $[\alpha]_{\mathrm{D}}^{25}-27$ (c 0.04, EtOH); IR (KBr) $v_{\max } 3381,2987,1650,1450,1407$, $1022 \mathrm{~cm}^{-1}$; UV (MeOH) $\lambda_{\max }(\log \varepsilon) 249$ (4.16), $259(4.23), 305(3.81) \mathrm{nm} ;{ }^{1} \mathrm{H}(400 \mathrm{MHz})$ and ${ }^{13} \mathrm{C}$ NMR (100 MHz) data, see Table 2; positive HR-ESIMS $m / z$ 515.1912 [M + H] $]^{+}$(calcd. for $\mathrm{C}_{27} \mathrm{H}_{31} \mathrm{O}_{10}, 515.1912$ ). 


\subsection{Determination of Aglycone Moieties and Sugars Configuration}

Compounds $1(2.0 \mathrm{mg}), \mathbf{2}(2.0 \mathrm{mg})$, and $\mathbf{3}(1.5 \mathrm{mg})$ were refluxed with $2 \mathrm{~mL}$ of $2 \mathrm{~N} \mathrm{HCl}$ and heated for $2 \mathrm{~h}$ at $80{ }^{\circ} \mathrm{C}$. After being neutralized with $\mathrm{NaHCO}_{3}$, the hydrolysate was extracted with EtOAc to separate the organic and aqueous layers. The organic layer was dried in vacuo and subjected to column chromatography using a Zorbax B-C18 column, mobile phase of $\mathrm{CH}_{3} \mathrm{CN} / \mathrm{H}_{2} \mathrm{O}(30: 70, v / v)$, flow rate of $1.5 \mathrm{~mL} / \mathrm{min}^{-1}$, and detection wavelength at $254 \mathrm{~nm}$. HPLC analysis of the aglycone-containing fractions of 1-3 gave peaks at 22.34, 22.38, and $22.46 \mathrm{~min}$, respectively, while the $t_{R}$ values for standard daidzein were observed at $22.47 \mathrm{~min}$, suggesting that the aglycone moieties of 1-3 were daidzein. The aqueous fraction was evaporated in vacuo and the sugar residue was dissolved in pyridine $(2 \mathrm{~mL})$ containing L-cysteine methyl ester hydrochloride $(1.0 \mathrm{mg})$, followed by heating at $60^{\circ} \mathrm{C}$ for $1 \mathrm{~h}$. A $25-\mu \mathrm{L}$ solution of $O$-tolylisothiocyanate was added to the mixture, which was heated at $60^{\circ} \mathrm{C}$ for a further $1 \mathrm{~h}$ [33]. Likewise, the $O$-tolylthiocarbamate derivative of 2-deoxy-L-fucose was prepared according to the method described above. Then, the $O$-tolylthiocarbamate derivatives were analyzed by reversed-phase HPLC (Amethyst C18-H, $5 \mu \mathrm{m}, 250 \times 4.6 \mathrm{~mm}$ inner diameter; $0.8 \mathrm{~mL} / \mathrm{min}^{-1} ; 250 \mathrm{~nm}$ ) eluting with $\mathrm{CH}_{3} \mathrm{CN} / \mathrm{H}_{2} \mathrm{O}(30: 70, v / v)$. Under these conditions, the derivative of standard sugar gave a peak at $t_{\mathrm{R}}$ $(\min )=25.06$, while $O$-tolylthiocarbamate derivatives of the liberated sugars of $\mathbf{1}-\mathbf{3}$ showed peaks at $25.40,25.02$, and $25.02 \mathrm{~min}$, respectively. The sugar moieties of the three new compounds (1-3) were identified as 2-deoxy-L-fucose.

\subsection{Biological Assays}

The antimicrobial activity of the three compounds against pathogenic fungi $C$. albicans, pathogenic bacteria methicillin-resistant $S$. aureus, and $E$. coli was investigated with the minimum inhibitory concentration (MIC) method recommended by the Clinical and Laboratory Standards Institute [34]. Gentamicin (an antibacterial antibiotic) and amphotericin B (an antifungal antibiotic) were used as a positive control.

The cytotoxicity of the three compounds was assayed in vitro against the human lung carcinoma cell line A549, hepatocellular liver carcinoma cell line HepG2, and the human colon tumor cell line HCT116 by the cell counting kit-8 (CCK8) colorimetric method. The cell lines were cultured in Dulbecco's Modified Eagle's Medium (DMEM) containing $10 \%$ calf serum at $37{ }^{\circ} \mathrm{C}$ for $4 \mathrm{~h}$ in a $5 \%$ $\mathrm{CO}_{2}$ incubator. The adherent cells of the logarithmic growth stage were digested and seeded in a 96-well culture plate at a density of $1 \times 10^{4}$ cells per/well. Test samples and control were added to the medium and incubated for $48 \mathrm{~h}$. Then, the cell counting kit-8 (CCK-8, Dojindo, Kumamoto, Japan) reagent was added to the medium and incubated for $3 \mathrm{~h}$. Cell viability was measured by absorbance at $450 \mathrm{~nm}$ using a SpectraMax M5 microplate reader (Molecular Devices Inc., Sunnyvale, CA, USA) [35]. The inhibitory rate of cell proliferation was expressed as $\mathrm{IC}_{50}$ values. Doxorubicin was used as a positive control, and cell solutions containing $0.5 \%$ DMSO were tested as a negative control.

\section{Conclusions}

The study was designed to isolate mangrove-derived Micromonospora strains and explore their bioactive metabolites. Fifty-one strains belonging to the genus Micromonospora were isolated, and the crude extracts of 12 isolates showed cytotoxic activity against the human lung carcinoma cell line A549. Furthermore, a chemical investigation was carried out on the strain M. aurantiaca 110B. This investigation led to the isolation of three new isoflavonoid glycosides (compounds 1-3). The structures of the new compounds were determined by NMR, HR-ESIMS, acid hydrolysis, and HPLC analysis on the $O$-tolylthiocarbamate derivatives of sugar moieties. Moreover, the three new compounds were the result of biotransformation by the strain M. aurantiaca 110B. The three compounds showed moderate activity against the human lung carcinoma cell line A549, hepatocellular liver carcinoma cell line HepG2, and the human colon tumor cell line HCT116. 
Supplementary Materials: The following are available online http://www.mdpi.com/1660-3397/17/5/294/s1: HR-ESIMS and NMR spectra (Figures S1-S29) of compounds 1-3, as well as other supporting data.

Author Contributions: R.-J.W. isolated strain 110B, new compounds, and prepared the manuscript. Y.-H.Y. and H.Q. tested the biological activities. S.-Y.Z. performed the spectroscopic data analysis. Z.Y. undertook the genome analysis. H.Z. and Z.-L.X. designed the experiments. J.-D.W. and M.W. determined the final structures of new compounds and guided the manuscript writing.

Funding: This work was supported by the China Ocean Mineral Resources R\&D Association (grant No. DY135-E2-2-05).

Acknowledgments: The authors thank Yu Liu (Life Science Institute of Zhejiang University) for performing NMR spectrometry.

Conflicts of Interest: The authors declare no conflict of interest.

\section{References}

1. Kathiresan, K.; Bingham, B.L. Biology of mangroves and mangrove ecosystems. Adv. Mar. Biol. 2001, 40, 81-251. [CrossRef]

2. Jiang, X.T.; Peng, X.; Deng, G.H.; Sheng, H.F.; Wang, Y.; Zhou, H.W.; Tam, N.F.Y. Illumina sequencing of $16 \mathrm{~S}$ rRNA tag revealed spatial variations of bacterial communities in a mangrove wetland. Microb. Ecol. 2013, 66, 96-104. [CrossRef]

3. $\mathrm{Xu}, \mathrm{J}$. Biomolecules produced by mangrove-associated microbes. Curr. Med. Chem. 2011, 18, 5224-5266. [CrossRef]

4. Gomes, N.C.M.; Borges, L.R.; Rodolfo, P.; Pinto, F.N.; Mendonça-Hagler, L.C.S.; Smalla, K. Exploring the diversity of bacterial communities in sediments of urban mangrove forests. FEMS Microbiol. Ecol. 2010, 66, 96-109. [CrossRef] [PubMed]

5. Thatoi, H.; Behera, B.C.; Mishra, R.R.; Dutta, S.K. Biodiversity and biotechnological potential of microorganisms from mangrove ecosystems: a review. Ann. Microbiol. 2013, 63, 1-19. [CrossRef]

6. Ghizelini, A.M.; Mendonça-Hagler, L.C.S.; Macrae, A. Microbial diversity in Brazilian mangrove sediments-A mini review. Braz. J. Microbiol. 2012, 43, 1242-1254. [CrossRef]

7. Hong, K.; Gao, A.H.; Xie, Q.Y.; Gao, H.; Zhuang, L.; Lin, H.P.; Yu, H.P.; Li, J.; Yao, X.S.; Goodfellow, M.; et al. Actinomycetes for marine drug discovery isolated from mangrove soils and plants in China. Mar. Drugs 2009, 7, 24-44. [CrossRef]

8. Abdelmohsen, U.R.; Bayer, K.; Hentschel, U. Diversity, abundance and natural products of marine sponge-associated actinomycetes. Nat. Prod. Rep. 2014, 31, 381-399. [CrossRef] [PubMed]

9. Velhopereira, S.; Kamat, N.M. Antimicrobial screening of actinobacteria using a modified cross-streak method. Indian. J. Pharm. Sci. 2012, 73, 223-228. [CrossRef]

10. Hirsch, A.M.; Valdés, M. Micromonospora: An important microbe for biomedicine and potentially for biocontrol and biofuels. Soil. Biol. Biochem. 2010, 42, 536-542. [CrossRef]

11. Euzéby, J.P. List of bacterial names with standing in nomenclature: A folder available on the internet. Int. J. Syst. Evol. Microbiol. 1997, 47, 590-592. [CrossRef]

12. Phongsopitanun, W.; Kudo, T.; Ohkuma, M.; Pittayakhajonwut, P.; Suwanborirux, K.; Tanasupawat, S. Micromonospora sediminis sp. nov., isolated from mangrove sediment. Int. J. Syst. Evol. Microbiol. 2016, 66, 3235-3240. [CrossRef] [PubMed]

13. Li, L.; Hong, K. Micromonospora ovatispora sp. nov. isolated from mangrove soil. Int. J. Syst. Evol. Microbiol. 2016, 66, 889-893. [CrossRef]

14. Zhang, L.; Li, L.; Deng, Z.; Hong, K. Micromonospora zhanjiangensis sp. nov., isolated from mangrove forest soil. Int. J. Syst. Evol. Microbiol. 2015, 65, 4880-4885. [CrossRef]

15. Li, L.; Tang, Y.L.; Wei, B.; Xie, Q.Y.; Deng, Z.; Hong, K. Micromonospora sonneratiae sp. nov., isolated from a root of Sonneratia apetala. Int. J. Syst. Evol. Microbiol. 2013, 63, 2383-2388. [CrossRef] [PubMed]

16. Songsumanus, A.; Tanasupawat, S.; Igarashi, Y.; Kudo, T. Micromonospora maritima sp. nov., isolated from mangrove soil. Int. J. Syst. Evol. Microbiol. 2013, 63, 554-559. [CrossRef] [PubMed]

17. Azman, A.S.; Othman, I.; Velu, S.S.; Chan, K.G.; Lee, L.H. Mangrove rare actinobacteria: taxonomy, natural compound, and discovery of bioactivity. Front. Microbiol. 2015, 6, 856. [CrossRef] 
18. Kyeremeh, K.; Acquah, K.S.; Sazak, A.; Houssen, W.; Tabudravu, J.; Deng, H.; Jaspars, M. Butremycin, the 3-hydroxyl derivative of ikarugamycin and a protonated aromatic tautomer of 5'-methylthioinosine from a ghanaian Micromonospora sp. K310. Mar. Drugs 2014, 12, 999-1012. [CrossRef]

19. Xu, D.B.; Ye, W.W.; Han, Y.; Deng, Z.X.; Hong, K. Natural products from mangrove actinomycetes. Mar. Drugs 2014, 12, 2590-2613. [CrossRef]

20. Al-Maharik, N.; Botting, N.P. An efficient method for the glycosylation of isoflavones. Eur. J. Org. Chem. 2008, 33, 5622-5629. [CrossRef]

21. Kang, H.R.; Lee, D.; Benndorf, R.; Jung, W.H.; Beemelmanns, C.; Kang, K.S.; Kim, K.H. Termisoflavones A-C, isoflavonoid glycosides from termite-associated Streptomyces sp. RB1. J. Nat. Prod. 2016, 79, 3072-3078. [CrossRef] [PubMed]

22. Fischer, C.; Rodriguez, L.; Patallo, E.P.; Lipata, F.; Braña, A.F.; Méndez, C.; Salas, J.A.; Rohr, J. Digitoxosyltetracenomycin $C$ and glucosyltetracenomycin $C$, two novel elloramycin analogues obtained by exploring the sugar donor substrate specificity of glycosyltransferase ElmGT. J. Nat. Prod. 2002, 65, 1685-1689. [CrossRef] [PubMed]

23. Parkinson, J.A.; Sadler, I.H.; Pickup, M.B.; Tabor, A.B. Complete assignment of the ${ }^{1} \mathrm{H}$ and ${ }^{13} \mathrm{C}$ NMR spectra and solution conformation of the antitumour antibiotic, aclacinomycin A. Tetrahedron 1995, 51, 7215-7222. [CrossRef]

24. Gui, C.; Yuan, J.; Mo, X.H.; Huang, H.B.; Zhang, S.W.; Gu, Y.C.; Ju, J.H. Cytotoxic anthracycline metabolites from a recombinant Streptomyces. J. Nat. Prod. 2018, 81, 1278-1289. [CrossRef] [PubMed]

25. Ndejouong, B.L.S.T.; Sattler, I.; Dahse, H.M.; Kothe, E.; Hertweck, C. Isoflavones with unusually modified B-rings and their evaluation as antiproliferative agents. Cheminform 2009, 43, 4548-4558. [CrossRef]

26. Bairoch, A.; Apweiler, R.; Wu, C.H.; Barker, W.C.; Boeckmann, B.; Ferro, S.; Gasteiger, E.; Huang, H.Z.; Lopez, R.; Magrane, M.; et al. The universal protein resource (UniProt). Nucleic. Acids. Res. 2005, 33, 154-159. [CrossRef]

27. Consortium, U.P. UniProt: A hub for protein information. Nucleic. Acids. Res. 2015, 43, 204-212. [CrossRef]

28. Lu, W.; Leimkuhler, C.; Oberthür, M.; Kahne, D.; Walsh, C.T. AknK is an L-2-deoxyfucosyltransferase in the biosynthesis of the anthracycline aclacinomycin A. Biochemistry 2004, 43, 4548-4558. [CrossRef]

29. Yu, X.Y.; Zhang, L.; Ren, B.; Yang, N.; Liu, M.; Liu, X.T.; Zhang, L.X.; Ding, L.X. Arthrobacter liuii sp. nov., resuscitated from Xinjiang desert soil. Int. J. Syst. Evol. Microbiol. 2015, 65, 896-901. [CrossRef]

30. Embley, T. The linear PCR reaction: A simple and robust method for sequencing amplified rRNA genes. Lett. Appl. Microbiol. 1991, 13, 171-174. [CrossRef] [PubMed]

31. Kim, O.S.; Cho, Y.J.; Lee, K.; Yoon, S.H.; Kim, M.; Na, H.; Park, S.C.; Jeon, Y.S.; Lee, J.H.; Yi, H.; et al. Introducing EzTaxon-e: A prokaryotic 16S rRNA gene sequence database with phylotypes that represent uncultured species. Int. J. Syst. Evol. Microbiol. 2012, 62, 716-721. [CrossRef] [PubMed]

32. Tamura, K.; Peterson, D.; Peterson, N.; Stecher, G.; Nei, M.; Kumar, S. MEGA5: Molecular evolutionary genetics analysis using maximum likelihood, evolutionary distance, and maximum parsimony methods. Mol. Biol. Evol. 2011, 28, 2731-2739. [CrossRef] [PubMed]

33. Chao, C.H.; Chou, K.J.; Huang, C.Y.; Wen, Z.H.; Hsu, C.H.; Wu, Y.C.; Dai, C.F.; Sheu, J.H. Steroids from the soft coral Sinularia crassa. Mar. Drugs 2012, 10, 439-450. [CrossRef] [PubMed]

34. Jorgensen, J.H.; Hindler, J.F.; Reller, L.B.; Weinstein, M.P. New consensus guidelines from the Clinical and Laboratory Standards Institute for antimicrobial susceptibility testing of infrequently isolated or fastidious bacteria. Clin. Infect. Dis. 2007, 44, 280-286. [CrossRef] [PubMed]

35. Wang, J.D.; Zhang, H.; Ying, L.P.; Wang, C.X.; Jiang, N.; Zhou, Y.; Wang, H.B.; Bai, H. Five new epothilone metabolites from Sorangium cellulosum strain So0157-2. J. Antibiot. 2009, 62, 483-487. [CrossRef] [PubMed]

(C) 2019 by the authors. Licensee MDPI, Basel, Switzerland. This article is an open access article distributed under the terms and conditions of the Creative Commons Attribution (CC BY) license (http://creativecommons.org/licenses/by/4.0/). 